\title{
Cultivation of Character Education Through Learning to Listen to Speech Based on Flash Media
}

\author{
in the Digital Age
}

\author{
Riswanda Himawan ${ }^{1}$, Ariesty Fujiastuti2 ${ }^{2}$, lis Suwartini ${ }^{3}$ \\ Riswanda.smki2016@gmail.com¹, ariestyfujiastuti@pbsi.uad.ac.id², iis.suwartini@pbsi.uad.ac.id³
}

\begin{abstract}
Every technology has a positive impact as well as a negative impact. The positive benefits that can be obtained from technological advances are to provide convenience in the field of education. The purpose of this paper is to find out how to instill character education through learning to listen to speech based on flash media in the digital era. This type of research is Reasrch and Development (R\&D). Development is done by developing learning media to listen to speech using Flash applications. The data collection method used a questionnaire. The feasibility instrument is reviewed from the learning media. The data analysis technique used is descriptive analysis technique. The final stage of this development is a feasibility and effectiveness test. Based on the research results, it can be seen that instilling character education can be done through learning to listen to speech using flash-based media. The value of the character of independence in this media can be seen from the form of media where users can access and download the desired material themselves.
\end{abstract}

Keywords: $\quad$ Character Education; learning media; speech; flash

Abstrak: $\quad$ Setiap teknologi pasti mempunyai dampak positif maupun dampak negatif. Manfaat positif yang bisa didapat dari kemajuan teknologi adalah memberikan kemudahan dalam bidang Pendidikan. Tujuan penulisan ini, yaitu untuk mengetahui bagaimana penanaman pendidikan karakter melalui pembelajaran menyimak pidato berbasis media flash di era digital. Jenis penelitian ini yaitu Reasrch and Develompent (R\&D). Pengembangan dilakukan dengan cara mengembangkan media pembelajaran menyimak pidato menggunakan aplikasi Flash. Metode pengumpulan data dengan menggunakan angket. Instrumen kelayakan ditinjau dari media pembelajaran. Teknik analisis data yang digunakan adalah teknik analisis deskriptif. Tahap akhir pengembangan ini adalah uji kelayakan dan efektifitas. Berdasarkan hasil penelitian dapat diketahui bahwa menanamkan pendidikan karakter dapat dilakukan melalui pembelajaran menyimak pidato dengan menggunakan media berbasis flash. Nilai karakter kemandirian dalam media ini dapat dilihat dari bentuk media yang mana pengguna dapat mengakses serta mengunduh sendiri materi yang diinginkan.

Kata Kunci: $\quad$ Pendidikan Karakter; media pembelajaran; pidato; flash

\begin{tabular}{|l|l|l|l|}
\hline Submitted: June 2020 & Reviewed: July 2020 & Accepted: August 2020 & Published: September 2020
\end{tabular}

\footnotetext{
1 Universitas Ahmad Dahlan

2 Universitas Ahmad Dahlan

3 Universitas Ahmad Dahlan
} 


\section{PENDAHULUAN}

ra 4.0 is an era of globalization, both in terms of technology, food and even education. The development of digital technology in the current Industrial 4.0 era has brought changes and influenced various aspects of human life, including in the field of education (Putrawangsa \& Hasanah, 2018). In this era everything can be said to develop even change. These changes are influenced by the flow of time that starts moving according to the current. For example in this 4.0 era technological advances that developed very rapidly indirectly affected all aspects of human life, both in the political, economic, cultural, even in the field of education.

Every technology must have both positive and negative impacts. Positive benefits that can be obtained from technological advancements are providing facilities in the field of education. One way that can be done is to use Flash as a learning media to listen to speeches for students which of course there are character values that can be developed in the media. Learning media is a tool to assist teachers in delivering a material to students so that it can be understood by students more easily. The function of this learning media is as a focus of students' attention when learning activities take place. Learning media also have many types including computer-based learning media in the interactive multimedia category using Adobe Flash software (Nur Lailiyah, 2018).

The use of flash-based media appropriately has become a technology of choice for creating dynamic and interactive learning media. Flash is software that has the ability to draw as well as animate and easy to learn. Flash is not only used in making animation, but in this day and age flash is also widely used for other purposes such as in game making, presentations, web building, learning animation, and even in film making (Giri Prasetyo, 2016). Macromedia flash provides an opportunity for children to develop emotional, physical, social and reasoning abilities of students ". Through its interaction with macromedia flash, a child learns to increase their tolerance for conditions that can potentially lead to high imagination of the child (Mardhatillah, 2018).

In the learning process, educators are required to be able to instill the values of character education towards students. However, there are no guidelines issued on how certain strategies and ways to instill character values to students in a learning. However, the most important thing is how the character's values arrive, are understood, embedded, and are expected to become permanent behavior in every student (Zafirah et al., 2018). Therefore, through learning media can also be used to instill the values of character education. The inculcation of character education in this media is the character of independence. Independent in this case is intended that students can access themselves and learn independently by using a flah-based media. In this learning lecturer does not explain the lecture method because the lecturer is only a facilitator. The second character value can be seen from the contents of the speech delivered the character to love the environment that is maintaining cleanliness. Through this speech, students can instill character education.

\section{RESEARCH METHODS}

This type of research is Reasrch and Develompent (R\&D). The development procedure used is the development procedure proposed by Borg and Gall. The research stages proposed by Borg and Gall are research and information collecting, planning, developing preliminary form a product, initial field testing, primary product revision, main field testing, operational product revision, functional field testing, final product revision, and dissemination and implementation. However, this research only reached the Main field testing stage. This research method is used to produce specific products and test the effectiveness of these products. This research method is used to produce certain products, and test the effectiveness of these products (Sugiyono, 2015). Data collection method using a questionnaire. The feasibility instrument is reviewed from the learning media. The data analysis technique used is descriptive analysis technique. The final stage of this development is the feasibility and effectiveness test. 


\section{RESULTS AND DISCUSSION}

\section{Research and information collecting}

Research and information collecting is done by analyzing needs. In this stage, the needs analysis is used to determine the state of learning to listen to speeches at PBSI UAD. Based on observations in the field, it is known that students need learning media due to the lack of teaching materials about speech material; students often do not understand the real purpose of speech learning material and cannot speak well. Some students have not yet reached the KKM score. This needs analysis consists of problem analysis and analysis of learning components. The study was conducted by interviewing and observing lecturers and students as potential users. Review in the field is carried out to find out the speech learning media, which is widely used as reference material for student learning and concludes the right speech learning media to be used as enrichment media.

\section{Problem analysis}

Problem analysis is done by interviewing and field observations about the speech learning media used in learning. The results of the study found that students have difficulty learning, especially for limited media. Students find it difficult because there is no medium for speech learning. Based on this analysis, the idea of making speech learning media was obtained. This is because learning media can contain material, examples of speeches, and more in-depth exercises. PBSI students are expected to be able to understand the various knowledge delivered in the speech learning media. By using teaching media, students can study at any time without any time restrictions such as on-campus due to limited learning hours, resulting in a lack of time, students have to explore learning material. The submission of competencies is delivered from a variety of systematically written sources. Lecturers act as facilitators, while students are also given the freedom and are directed to actively and creatively look for other relevant sources. Learning using speech learning media enables lecturers to understand students better so that obstacles in learning can be more quickly overcome. Learning to use media is more beneficial for both students and teachers.

\section{Learning Component Analysis}

Analysis of the learning component is done by library research. A literature study was conducted to obtain a source of guidance and material for the development of speech learning media. The initial phase is to do a guideline study that will be used as a reference in developing statement learning media and then gathering relevant material. The material that will be outlined in the learning media is expected to be able to meet the learning outcomes of study programs, course achievements, and indicators so that learning objectives can be achieved.

\section{Planning}

The design of speech learning media starts with gathering material. The collection of reference material in this study includes (a) reviewing the curriculum based on the existing RPS so that the resulting instructional learning media does not deviate from the learning objectives at PBSI UAD, (b) Dialogue with lecturers, this is done to find out which materials need media assistance learning speech learning and identifying the types of speech learning media that are presented in order to attract the attention of students and statement learning media that have been made can improve learning outcomes, and (3) identify needs based on RPS and indicators so that learning objectives can be achieved as expected. After collecting the material, the researcher made a powerpoint. The content that has been selected is then included in the powerpoint to make it easier to create media using flash.

\section{Develop preliminary from a product}


This stage is the initial development of listening to listening to speech media products. The initial development was carried out by compiling learning media after composing the material using power points and then compiling using flash. At this stage, the media are produced of learning indicators, equipment, sample speeches, and practice questions.

\section{Preliminary field testing}

At this stage, the initial examination is carried out, namely by testing media experts and material experts. The data obtained shows the level of validity of the feasibility of the media as a source of learning. The suggestions contained in the instrument are used as consideration for further improvement of the media. The following are the test results from each validator.

Learning Media Expert. Media Learning experts provide advice from sections contained in speech teaching media. After the material expert conducts an assessment, things that must be revised are known. Based on the calculation of the feasibility of teaching media in terms of aspects of the media included in the very feasible category of 2 or $66.7 \%$ and the possible category of 1 or $33.3 \%$. This shows that the speech learning media has met the criteria very reasonable to be used as a right learning media.Ahli Materi Pembelajaran.

Expert Learning Materials. Material experts provide advice from sections contained in speech learning media. After the material expert conducts an assessment, things that must be revised are known. Based on the calculation of the feasibility of teaching media in terms of aspects of the media included in the very feasible category of 3 or $75 \%$ and the possible category of 1 or $25 \%$. This shows that the speech learning media has met the criteria very reasonable to be used as good learning material.Main product revision

At this stage, the researchers improve the media that have been made based on the results of evaluations from the material experts and media experts. The following suggestions are given by experts, which are as follows.

Table 1. Media Expert Advice

\begin{tabular}{lll}
\hline No. & \multicolumn{1}{c}{ Saran } & \multicolumn{1}{c}{ Tindak lanjut } \\
\hline 1. & $\begin{array}{l}\text { The use of language in rhetorical learning } \\
\text { media needs to be adapted to the } \\
\text { standard language }\end{array}$ & Repaired following the experts' advice \\
2. & The voice is clarified & Repaired following the experts' advice \\
3. & Animation needs to be added & Repaired following the experts' advice \\
4 & Images need to be added & Repaired following the experts' advice \\
5 & The image is made more proportional & Repaired following the experts' advice \\
6 & Material added & Repaired following the experts' advice \\
\hline
\end{tabular}

Based on table 1, it is known that advice from the Experts relates to the material and use of language, images, sound, and animation. The information given was well received by the researchers and revised according to the advice given by the Experts.

Main field testing. At this stage, the main field trial is carried out on students. The following explanation.

Material Conformity Aspect. The feasibility of learning media in terms of the suitability of the material included in the very feasible category is 35 or $87.5 \%$, and the available class is 5 or $12.5 \%$. This shows 
that the suitability of the material in the learning media has met the criteria very feasible to be used as the right learning media.

Learning Media Aspects. The feasibility of instructional learning media from the aspect of instructional media is included in the very feasible category of 25 or $62.5 \%$ and the possible category of 15 or $37.5 \%$. This shows that the aspects of instructional media in learning media have met the criteria very feasible to be used as the right learning media.

Aspects of Assessment of Overall Learning Media. The feasibility of teaching media in terms of the overall evaluation of learning media included in the very feasible category of 31 or $77.5 \%$, and the possible type of 9 or $22.5 \%$. This shows that the learning media as a whole has met the criteria very feasible to be used as a right learning media.

Based on the results of the study, it can be seen that the learning media listening to speeches is very feasible and can be used in the learning process for both lecturers and students. It can be seen that the assessment of the feasibility level of learning media listening to the speech as a whole obtained valid and very decent results. Character education that can be applied in this media can be seen in terms of character education through listening to speeches and in terms of flash media in the digital age. The following explanation.

The word character comes from the Greek charassein, which means to engrave (painting, drawing), like people who paint paper, sculpt stone or metal. Rooted in such an understanding, character is then interpreted as a sign or a special feature, and therefore gives birth to the view that character is a 'pattern of behavior that is individual, one's moral state'. After passing through the stage of children, a person has a character, a predictable way that a person's character is related to the behavior that is around him. Formation of character in the world of education is very necessary. Learning is not only limited to providing understanding of teaching material. Learning should emphasize the formation of children's character from an early age. These character values are born from the local wisdom of Indonesian culture such as moral values, social, religious customs and traditions that apply in Indonesia. Based on research (Pattaro, 2016), character education in each country emphasizes moral reasoning, cognitive development, social and emotional learning, moral education, civic education, life skills education, community care, prevention of risk behavior and many others.

Character education must be applied in the learning process. This is because, character education can improve student learning outcomes. This opinion is in line with that delivered by (Sardjijo \& Ali, 2017), which states that the application of character's model specifically seems to be child-centered, giving immediate experience, providing concepts of various fields of study within one learning process by integrating character building ; the learning result can develop in accordance with children interests and needs, meaningful, holistic, flexible and active. Character education needs to be developed in various aspects including learning materials in listening to speeches. It's time to replace traditional learning with character learning. Based on research (Tannir \& Anies, 2013), which shows that students who received character education showed slight progress in their self-esteem score, whereas students in the traditional instructional group did not show any progress in their self-esteem. In fact, students in the non-treatment group showed a regression in their self-esteem scores based on the RSS tool.

Building the character of the nation must be gradual and sustainable. For this reason, strategic steps are needed. The Ministry of National Education has launched a national character education movement that began on May 2, 2010, as evidenced by the process of preparing a national action plan (RAN) for character education and preparation for the grand design of character education in education units ( Furkan, 2014). Indonesia has sought to develop character education that is integrated in subjects at both the student and student levels. Character education curriculum is the concept of a curriculum that is designed as a learning experience. In this context, the curriculum is not a sense in terms of material, but 
rather a learning experience that is designed for learners (Hidayat, M. Zaim, Rukun, \& Darmansyah, 2014). There are three focuses of character education. First, the character education focuses on teaching values. Second, it focuses on the clarification value. And the last, it focuses on the Kohlberg's moral development (Agung, 2011). These three aspects are very important to develop character education. Character education that focuses on teaching values based on moral values. The value of clarification includes moral identification and value selection. The character traits should include, courage, good judgment, integrity, civility, kindness, perseverance, responsibility, tolerance, self-discipline, respect for school personnel, responsibility for school safety, service to others and good citizenship (Pala, 2011).

Character education that can be applied through listening to learning is seen from the content in the speech sample. The speech persuades the listener to maintain cleanliness, so it can be concluded that when viewed from the contents of the speech the character developed is the character of awareness in maintaining cleanliness. Second, when viewed from the contents of the speech. The speech persuaded the listeners to maintain cleanliness, so it can be concluded that when viewed from the contents of the speech the characters developed were characters of awareness in maintaining school or campus hygiene, such as not throwing away rubbish, separating between plastic, paper and glass. Digitalization has changed and transfigured media and communication technology. Automatic telephone networks that were previously operated manually can now be operated by computer intellect-netting devices with software capable of configuring intelligent networks with complex digital features.

The benefits of using Educational learning media, namely: 1) clarifying the message so as not to be too verbalistic; 2) overcome the limitations of space, time energy and sense power; 3) generate enthusiasm for learning, more direct interaction between students and learning resources; 4) enable children to learn independently according to their talents and visual, auditory and kinesthetic abilities; 5) giving the same stimulation, equalizing experiences and giving rise to the same perception (Daryanto, 2010). Hamalik in (Arsyad, 2015), argues that the use of instructional media in the teaching and learning process can arouse new desires and interests, generate motivation and stimulation of learning activities, and even bring the influence of psychological influence on students. Learning media listening to speeches through flash media is one form of globalization in terms of technology, because almost all parts of this learning media are the result of technological advancements, starting from the use of tools namely devices, laptops and so on. Flash At the beginning of its appearance Flash is more widely used to support the appearance of animation on websites, because of the ability of graphics and data processing support, many people use it to make offline applications. Macromedia Flash is an authoring tool that has the ability to develop almost all multimedia applications.

With Actionscript programming on Macromedia Flash animation and visualization can be made relating to the presentation of information, such as quizzes, puzzles, and other interactive applications such as product catalogs, company profiles, or tutorials that can be packaged on CD. Macromedia Flash 8 has the ability to read XML-based data. With this capability, data based applications can be made without being dependent on PHP, ASP, or other server side scripting languages. Without this dependency, there is no need for a database server or even a web server. This flash media-based listening learning media is designed to facilitate the learning process of students because students only need a device or laptop to access this learning media. Besides that, students will also feel the benefits of digital device technology. So that will provide evidence that the device does not always have a negative effect, but there is a positive value that can be used as a medium in learning and interacting with surrounding environment. This media is one form of the digitalization era, which provides evidence that listening to speech activities can be carried out through devices with learning media applications, namely flash, which so far students can only access YouTube if they want to access videos of listening activities such as speeches. So that with this learning media can make it easier for students who will learn one of the language skills that one example is speech. 
In this media all information about speech learning is available starting from the understanding of speech, the procedure for speech, the attitude in speech, to display examples of speech delivery well and in accordance with existing rules and regulations as well as examples of questions. In this media the characters developed are students who are required to have the character of independence. This is because, in this media students must actively search for the desired material. The task of the lecturer is only as a facilitator, secondly when viewed from the content of the speech. The second character can be seen from the contents of the speech delivered, namely the characters about caring for nature, maintaining cleanliness of the school or campus environment, such as not littering, not scribbling walls, and behaving clean and healthy living in a school or campus environment, so will create students who excel because of a healthy campus environment. It is hoped that besides this media can also train the independence of students so as not to depend on others in life, students can actively search for the materials needed, and students can learn privately, anywhere and anytime. In this media students can also directly access material about speeches, such as speech understanding, speech objectives, how to deliver speech according to rules, and so on. So that students will more easily understand because of the effectiveness of this media, students can also use their devices for learning purposes, so that they do not only play games in the device, but can use the device as a source of learning in lectures.

\section{CONLUSIONS AND RECOMMENDATIONS}

Based on the results of the study, it can be seen that the learning media listening to speeches is very feasible and can be used in the learning process for both lecturers and students. It can be seen that the assessment of the feasibility level of learning media listening to the speech as a whole obtained valid and very decent results. This learning media is designed to deal with the digitalisation era, besides that in this media there are also character values that can be developed, including the character of independence and also the character for love for nature, nature in this context is the environment. The value of independence character in this media can be seen from the form of media where users can access and download the desired material themselves, the value of the character of nature's love in this case can be seen from the contents of the speech which will directly preserve listening to both protecting the environment. Hopefully with this media students can add to the excitement of students in learning, because this application is designed to be very practical and easy, so that student achievement will increase because of independence.

\section{REFERENCES}

Arsyad, A. (2015). Media Pembelajaran. Jakarta: PT Raja Grafindo Persada. Daryanto. (2010). Media Pembelajaran. Yogyakarta: Gaya Media.

Giri Prasetyo, L. D. P. (2016). Pengembangan adobe flash pada pembelajaran tematik- integratif berbasis scientific approach subtema indahnya peninggalan sejarah. Jurnal Prima Edukasia, 4(1), 54-66.

Mardhatillah, E. T. (2018). Pengembangan Media Pembelajaran Pengembangan media pembelajara berbasis macromedia flash untuk meningkatkan kemampuan membaca siswa di SD kelas II Negeri Paya Peunaga kecamatan Meurebo. Bina Gogik, 5(1), 91-102.

Nur Lailiyah, W. S. (2018). Pengembangan Media Pembelajaran Interaktif Berbasis Flash Untuk Pembelajaran Keterampilan Menuliskan Kembali Cerita Siswa Kelas Iv Sd. Jurnal Penelitian Pendidikan Guru Sekolah Dasar, 6(7), 1150-1159.

Putrawangsa, S., \& Hasanah, U. (2018). INTEGRASI TEKNOLOGI DIGITAL DALAM

PEMBELAJARAN DI ERA INDUSTRI 4.0Kajian dari Perspektif Pembelajaran Matematika. Jurnal Tatsqif, 16(1), 42-54. Retrieved from http://journal.uinmataram.ac.id/index.php/tatsqif/article/view/203/124

Sugiyono. (2015). Metode Penelitian dan Pengembangan (Research and Development/R\&D). Bandung: Alfabeta. 
Zafirah, A., Aini, F., Engkizar, Anwar, F., Alvi, A. F., \& Ernawati. (2018). Penanaman nilai-nilai karakter terhadap peserta didik Melalui permainan congkak sebagai media pembelajaran. Jurnal Pendidikan Karakter, 8(1), 95-104. https://doi.org/10.21831/jpk.v8i1.21678

How to cite: Himawan, R., Astuti, F., Suwartini, I. (2020). Cultivation of character education through Learning to Listen to speech based on flash media in the digital age. Teknodika, 18 (2), 116-123. DOI: https://doi.org/10.20961/teknodika.v18i2.41993 